SJ Quinney College of Law, University of Utah Utah Law Digital Commons

$1-2020$

George Perkins Marsh: Anticipating the Anthropocene

Robin Kundis Craig

Follow this and additional works at: https://dc.law.utah.edu/scholarship

Part of the Environmental Law Commons, and the Natural Resources Law Commons 


\title{
George Perkins Marsh: ANTICIPATING THE ANTHROPOCENE
}

\author{
Robin Kundis Craig*
}

In 1864, George Perkins Marsh explored the impacts that human beings were already having on the physical and chemical processes of the world's ecosystems in Man and Nature or, Physical Geography as Modified by Human Action, republished in 1874 as The Earth as Modified by Human Action. ${ }^{1}$ Often hailed as "America's first environmentalist," Marsh anticipated-or, perhaps more accurately, recognized the first signs of - the Anthropocene, the era in which human interactions with ecological processes at multiple scales has become the major driver of planetary function and dysfunction. He also helped to inspire new directions in natural resource management, law, and policy, including forest preservation and restoration, fisheries management, and landscape-scale water management.

Context always matters to important thinkers, and it is probably not a coincidence that Marsh was particularly well-positioned temporally and geographically to observe firsthand humans' ability to alter landscapes. Marsh was born in 1801 and grew up in Vermont. His ties to early-19th century New England are crucial to the vision of human influence on nature he later developed: "By 1800, New England was one of the longest settled and most densely populated of the country's regions, and in the first half of the nineteenth century it became the national crucible of a commercial and industrial revolution that was to transform America."2 The changes occurring in New England were both still fresh in memory - the American Revolution was barely a generation into the past - and still happening, allowing for Marsh to become a personal witness to

* James I. Farr Presidential Endowed Professor of Law, University of Utah S.J. Quinney College of Law, Salt Lake City, UT 84112. The author may be reached at robin.craig@law.utah.edu.

${ }^{1}$ Marsh wrote his most influential work for environmental and natural resources law in the 1850s through 1870s, and his language reflects the usage of his day, where "man" and "humanity" were interchangeable and Nature was almost always personified as female. In addition, as will become clear, he accepts European colonialism without much comment as to the fates of indigenous peoples, although colonization did mean for Marsh the beginning of the degradation of natural systems. While I acknowledge that these usages and attitudes today would subject Marsh to a thorough edit for latent sexism and racism, I have chosen, other than in this footnote, to let his language stand without comment, viewing it as an historical artifact in its own right.

2 Robert L. Dorman, A Word For Nature: Four Pioneering Environmental Advocates, 1845-1913, at 5 (University of North Carolina Press: 1998). 
humanity's increasing ability to engineer landscapes, especially by felling forests. Moreover, the United States still an active but constantly developing frontier throughout Marsh's life: Thomas Jefferson's Louisiana Purchase occurred in 1803; Lewis and Clark went on their expedition of discovery between 1804 and 1806; the United States annexed Texas in 1845; Mexico and the United States entered the Treaty of Guadalupe Hidalgo in 1848, giving the United States new territories in the Southwest; men seeking fortunes flocked to the California Gold Rush between 1848 and 1885, with California becoming a state in 1850; President Abraham Lincoln signed the first Homestead Act into law in 1862, encouraging settlement of the West; and the United States purchased Alaska in 1867. The national transportation network of railroads was built; "[n]one had existed as late as the $1820 \mathrm{~s}$, but by the $1850 \mathrm{~s}$ the United States encompassed more miles of track than the rest of the world combined." Americans were building other things, as well, including "scores of dams, [] hundreds of miles of canals, and [] thousands of miles of roads ...."4 The young nation's population grew from 5 million at the Revolution to 31 million in 1860, but it was also shifting west and was centered west of the Appalachian Mountains for the first time right before the Civil War. The period before the civil war also experienced the highest rate of urbanization in United States history. A changing national map, the progressive acquisition of new landscapes, and the European-American settlement and transformation of new territories were thus the constant and unavoidable realities of Marsh's life.

By the age of seven, Marsh suffered from strained and damaged eyesight from intensive reading. The treatment was to send him outdoors, ${ }^{5}$ and he became an avid walker and fisherman. As a boy in Woodstock, Vermont, he observed firsthand what deforestation was doing to the landscape, particularly in terms of water supply. Thirty years of settlement had rapidly deforested the area surrounding Woodstock, as residents converted the once-abundant forests into farms, firewood, and potash. ${ }^{6}$ A frequent user of the Quechee River, Marsh noticed "that the spring freshets grew increasingly violent as more trees were cut into the hills" but also that in the summer streams and rivers increasingly dried up, making summer fishing less and less productive over time. ${ }^{7}$ Aided by his lawyer-father's instruction as they toured the New England landscape, Marsh recalled beginning to understand how the various physical facets of nature worked together:

"My father pointed out the most striking trees as we passed them, and told me how to distinguish their varieties. I do not think I ever afterward

\footnotetext{
${ }^{3} I d$. at 6.

${ }^{4}$ Id.

5 Jane Curtis, Will Curtis, \& Frank Lieberman, The World of George Perkins Marsh 13 (1982).

${ }^{6}$ David Lowenthal, George Perkins Marsh: Prophet of Conservation XX (2000) (Chapter 1).

${ }^{7}$ CuRTis, Curtis, \& Lieberman, supra note 5, at 15.
} 
failed to know one forest tree from another. He called my attention to the general configuration of the landscape, pointed out the direction of the different ranges of the hills, told me how the water gathered on them and ran down their sides, and where the mountain streams would likely be found. But what struck me, perhaps most of all, he stopped his horse on top of a steep hill, bade me notice how the water there flowed in different directions, and told me such a point was called a water-shed. . . . I never forgot that word, or any art of my father's talk that day." 8

In addition, at school in Royalton, Vermont, starting in 1811, the 10-year-old fisherman also observed the striking differences between the forested streams of his home and the thoroughly deforested White River.

Despite his eyesight, Marsh remained a voracious lifetime scholar-but he was also a 19th-century Renaissance man. Over the course of his varied and often unsuccessful careers, he taught Greek and Latin at the Norwich American Literary Scientific and Military Academy, advocated training in sign language for deaf-mutes, practiced law in Burlington, Vermont (reflecting much later, in 1875, that "[o]nly odd or perverse people go into law"), "amassed one of the largest collections of Scandinavian literature" in the United States, ${ }^{10}$ lectured on "The Goths in New England" (1843) and produced dictionaries of American English, raised sheep and ran a woolen mill, worked as a quarryman, contributed as an amateur architect to the designs for the Washington Monument and the Vermont State House, collected art, invested in railroads, and convinced the U.S. military to adopt camels for use in the American West. Marsh was also a politician, serving first in Vermont's General Assembly and then in Congress, as an anti-slavery and pro-protective tariff Whig, for two terms beginning in 1843. As a member of the Joint Library of Congress Committee and then the seven-man Smithsonian Select Committee, Marsh exhorted his fellow congressmen to use the founding $\$ 500,000$ bequest from James Smithson to create national museums and research institutions rather than to support practical training in agriculture and experimental science. His efforts, together with those similarly-minded individuals like John Quincy Adams, eventually bore fruit, as the Smithsonian Institution became a place of knowledge and research as well as a home to various natural history collections. Marsh himself became a Smithsonian trustee.

Marsh's post-Congress public service fed the observations that would help shape Man and Nature. Proficient in languages from an early age, Marsh eventually spoke about 20 of them, contributing to his qualifications for the diplomatic service. Beginning in

\footnotetext{
${ }^{8} I d$. at $15,18$.

${ }^{9}$ LOWENTHAL, supra note 6, at XX (Chapter 2, after fn 6).

${ }^{10} \mathrm{Id}$. at XX (Chapter 1, fn 41) (quoting CAROLINE CRANe MARSH, LiFE AND LetTers of George Perkins Marsh 7 (1888)); see also Curtis, Curtis, \& Lieberman, supra note 5 , at 25 (quoting the same language).
} 
1849, under appointment by newly-elected President Zachary Taylor, Marsh served as the United States Minister in Residence to the Ottoman Empire (Turkey), a post that allowed him to travel to Paris, Rome, Nubia, Egypt, and the Holy Land, and that included an assignment to unravel a complex land dispute in Athens. Exploring the transformed landscapes of Greece and Turkey, he could see even more profoundly than he had in New England the long-term results of human interactions with their environments, and over a longer temporal scale. "It was here Marsh first saw that men had everywhere left their mark; soon he realized how far that touch had transformed nature. The mangled forests and disrupted rivers of New England had already shown him the immediate impact of human improvidence; the deserts of the Levant revealed the ultimate effects of similar processes when long continued." "11 Marsh also collected specimens and set up museum swaps for the Smithsonian.

After President Pierce appointed Marsh's successor to Turkey in late 1953, Marsh spent a year traveling in Europe. Significant financial difficulties kept Marsh in a battle with Congress to get paid for his diplomatic expenses, and during this time he gave a series of lectures that tried to educate Americans that they needed to start conservation efforts if they were to avoid the fate of many European landscapes. Americans, he argued, "were 'already beginning to suffer from the washing away of vegetable soil from our steeper fields, and from the drying up of the abundant springs which one watered our hill pastures, and from the increased violence of our spring and autumnal freshets." 12 Europe revealed where these processes were going, because "only in countries that have been laid bare ... for generations [could] the extent of the devastation thus produced be comprehended.",13 Marsh recommended a number of land management reforms to avoid the geographical transformations he had seen in Europe and the Near East, including logging prohibitions on steep slopes. grazing restrictions, mandated reforestation, and stream conservation. ${ }^{14}$

Eventually, in 1957, Vermont's governor, Ryland Fletcher, appointed Marsh to the positions of Vermont Railroad Commission, Fish Commissioner, State House Commissioner, and head of the Ethan Allen Monument Committee. From his position as Fish Commissioner, in particular, Marsh once again observed the deep and long-term human impacts on natural systems. "Fishing in Vermont was now even worse than it had been in his boyhood. The Legislature had passed act after act to protect what was left, but the plump salmon, the silvery trout had all but vanished from the waters" ${ }^{\text {"15; }}$, the former had been extirpated as a result of dam building, while the latter had been eaten to extinction by the pickerel that early settlers had introduced to Vermont's streams and

${ }^{11}$ LOWENTHAL, supra note 6, at XX (end of Chapter 6).

${ }^{12}$ Id. at XX (Chapter 8) (quoting Marsh's public lectures).

${ }^{13} I d$. (quoting Marsh's public lectures).

${ }^{14} \mathrm{Id}$.

${ }^{15}$ Curtis, Curtis, \& Lieberman, supra note 5, at 94. 
rivers. ${ }^{16}$ Marsh recognized that the causes of the loss were complex, encompassing not only over-fishing and dam building. Indeed,

"other and more obscure causes have had a very important influence on producing the same result ... much must doubtless be ascribed to the general physical changes produced by the clearing and cultivating of the soil. ... It is certain that while the spring and autumnal freshets are more violent, the volume of water in the dry season is less in al our water courses than it formerly was, and there is no doubt that the summer temperature of the brooks has been elevated.... The clearing of the woods has been attended with the removal of many obstructions to the flow of water. . . . The general character of our water courses has become in fact more torrential. . . . In inundations, not only does the mechanical violence of the current destroy or sweep down fish and their eggs, and fill the water with mud and other impurities, but it continually changes the bed and banks of the streams, and thus renders it difficult and often impossible for the fish ... to return to their breeding places and deposit their spawn." ${ }^{17}$

Humans, Marsh concluded, had been the architects of physical, chemical, and ultimately biological changes that they now lamented, and "it is enough to say that human improvements have produced an almost total change in all the external conditions of piscatorial life . . . and we must of course expect that the number of fish will be greatly affected by those revolutions." 18 In his fisheries report, Marsh recommended careful use of fish breeding and restocking, with controls to prevent the harmful side effects that he had seen in Europe. As a start, "he proposed restocking Lake Champlain with the shad, salmon, and trout "which formerly furnished so acceptable a luxury to the rish, and so cheap a nutrient to the poor of Western Vermont, but which now are become almost as ... extinct as the game that once enlivened our forests." "19 In addition, Marsh exhibited a thorough understanding of the complex interrelationships among species and even a nascent version of what has now been dubbed "ecosystem services," chastising Vermonters for their "mistaken prejudices" against "birds, quadrupeds, and reptiles" because of the supposed damage they inflict

${ }^{16}$ LOWENTHAL, supra note 6, at XX (Chapter 9, near fn 5).

${ }^{17}$ Curtis, Curtis, \& Lieberman, supra note 5, at 94 (quoting George Perkins Marsh, Report, on the Artificial Propagation of Fish 19-21 (1857)).

${ }^{18}$ Id. (quoting George Perkins Marsh, Report, on the Artificial Propagation of Fish 1921 (1857)).

${ }^{19}$ Lowenthal, supra note 6, at XX (Chapter 9, fn 6) (quoting George Perkins Marsh, Report, on the Artificial Propagation of Fish 19-21 (1857)). 
upon crops. Instead, Marsh argued, "they 'much more than compensate the little injury they inflict upon the crops' by consuming 'vast numbers of noxious insects.", 20

The Vermont Legislature praised Marsh's report but declined to act on it. However, fifteen years later, Spencer Baird, U.S. Commissioner of Fish and Fisheries and a Marsh protégé, relied heavily on Marsh's fish report in his own 1872-1873 federal fisheries report. Baird credited Marsh with initiating salmon restoration efforts in the United States and adopted Marsh's conservation approach for federal fisheries management. ${ }^{21}$ As such, "Marsh had played a truly pioneering role" in U.S. fisheries management and policy. ${ }^{22}$

Marsh ended his career, and life, as the U.S. Minister to the newly-formed country of Italy, in which position he died in 1882. Appointed by President Lincoln, Marsh left the United States eleven days before the American Civil War broke out in 1861. After Lincoln's assassination, first President Johnson and then President Grant kept him on as Minister. Marsh wrote Man and Nature from Italy, and the book was published in 1864, with a second revised edition appearing in 1874 and a third, posthumous, edition in 1885 .

In Man and Nature, Marsh posited that humans were geological agents, transforming geographic, physical, and chemical processes through the changes - both modest and extravagant - that they bring to natural systems. He was the first person to offer such a theory, and he "was considered by many as a radical crank," because "[ $t]$ he conventional idea held by his contemporaries ... was that the physical aspect of the earth was entirely the result of natural phenomena, mountains, rivers, oceans." 23 He focused on the great transformational activity of his day: deforestation. Specifically, he sought " "to show the evils resulting from too much clearing and cultivation, and often so-called improvements in new countries like the United States." "24 However, his observations remain highly relevant and generalizable beyond the cutting of trees and even anticipate in many ways the premise of Jared Diamond's Collapse.

Man and Nature is a historic and geographic tour de force. All of human history, all of natural history, and all geographies are with Marsh's scope. As one commenter notes, "The immediate sources of Man and Nature are wildly heterogeneous. Interspersed with excerpts from French engineers on stream abrasion and German foresters on tree physiology are piquant anecdotes from Marsh's boyhood and travels." 25 Man and Nature

${ }^{20}$ Id. at XX (Chapter 9, fn 14) (quoting George Perkins Marsh, Report, on the Artificial Propagation of Fish 10-11 (1857)).

${ }^{21}$ Id. at XX (Chapter 9, near fn 8).

${ }^{22} I d$.

${ }^{23}$ Curtis, Curtis, \& Lieberman, supra note 5, at 102.

${ }^{24}$ Lowenthal, supra note 6, at XX (Chapter 13, fn 2) (quoting letter from George Perkins Marsh to Secretary of State William H. Seward, July 7, 1863).

${ }^{25}$ Id. at XX (Chapter 14, before fn 22). 
begins, for instance, with the natural advantages that the Roman Empire enjoyed, only to have Marsh graphically describe the degradation that has since occurred:

If we compare the present physical condition of the countries of which I am speaking, with the descriptions that ancient historians and geographers have given of their fertility and general capability of ministering to human uses, we shall find that more than one-half of their whole extent - and not excluding the provinces most celebrated for the profusion and variety of their spontaneous and their cultivated products, and for the wealth and social advancement of their inhabitants - is either deserted by civilized man and surrendered to hopeless desolation, or at least greatly reduced in productiveness and population. Vast forests have disappeared from mountain spurs and ridges; the vegetable earth accumulated beneath the trees by the decay of leaves and fallen trunks, the soil of the alpine pastures which skirted and indented the woods, and the mould of the upland fields, are washed away; meadows, once fertilized by irrigation, are waste and unproductive because the cisterns and reservoirs that supplied the ancient canals are broken, or the springs that fed them dried up; rivers famous in history and song have shrunk to humble brooklets; the willows that ornamented and protected the banks of the lesser watercourses are gone, and the rivulets have ceased to exist as perennial currents, because the little water that finds its way into their channels is evaporated by the droughts of summer, or absorbed by the parched earth before it reaches the lowlands; the beds of the brooks have widened into broad expanses of pebbles and gravel, over which, though in the hot season passed dryshod, in winter sealike torrents thunder; the entrances of navigable streams are obstructed by sandbars; and harbors, once marts of an extensive commerce, are shoaled by the deposits of the rivers at whose mouth they lie; the elevation of the beds of estuaries, and the consequently diminished velocity and increased lateral spread of the streams which flow into them, have converted thousands of leagues of shallow sea and fertile lowland into unproductive and miasmatic morasses. $^{26}$

While some of this change, Marsh admitted, resulted from natural forces and human violence, "a far greater proportion" is "either the result of man's ignorant disregard for the laws of nature, or an incidental consequence of war and of civil and ecclesiastical tyranny and misrule." 27 Moreover, while humanity seems puny compared to the forces of geography and climate, "it is certain that man has reacted upon organized and inorganic

${ }^{26}$ George Perkins Marsh, The Earth as Modified by Human Action 20 (1878).

${ }^{27}$ Id. at 21. 
nature, and thereby modified, if not determined, the material structure of his earthly home." 28

Marsh acknowledged that he could not provide quantitative proof of humanity's influence on geography and climate, ${ }^{29}$ only qualitative observations - his own; instead, his aim "was to stimulate, not to satisfy, curiosity . . ." "30 He nevertheless started with some basic observations. First, climate and geography matter to what can grow and thrive in specific locations. ${ }^{31}$ Second, life can adjust over time to new conditions, as evidenced by the fact that introduced species such as maize and the tomato have adjusted over time to their new locations. ${ }^{32}$ Third, we know from a variety of examples that both human farming and human engineering can change the character of a place's water resources: clearing of forests, whether in central Africa, Arabia, or California, tends to dry out that locality, while as a result of "injudicious husbandry, or the diversion or choking up of natural water-courses, [an area] may become more highly charged with humidity." ${ }^{, 3}$

Part of the importance of Man and Nature lies in Marsh's keen recognition that the environment is a system - that "the organic and inorganic world are . . . bound together by such mutual relations and adaptations as secure, if not the absolute permanence and equilibrium of both, a long continuance of the established conditions of each at any given time and place, or at least, a very slow and gradual succession of changes in these conditions." ${ }^{, 34}$ Thus, he argues at great length that plant and animal life are relevant to modern geography, ${ }^{35}$ and he recognizes that ecosystems affect climate and the weather as much as climate and weather affect ecosystems. Forests, for example, influence meteorology, the mixture of gases in the atmosphere, and the distribution of heat. ${ }^{36}$ Marsh also postulated that forests reduce malaria by breaking up "miasmatic vapors"37; Sir Ronald Ross did not discover the role of mosquitoes in malaria transmission until 1897. Forests also shape the landscape itself: trees shelter ground leeward of the prevailing winds. ${ }^{38}$ It total, "in countries in the temperate zone still chiefly covered with wood, the summers would be cooler, moister, shorter, the winters milder, drier, longer, than in the same regions after the removal of the forest, and that the

${ }^{28} I d$. at 24.

${ }^{29} I d$. at 28.

${ }^{30} \mathrm{Id}$. at 26.

${ }^{31} I d$. at $30-31$.

${ }^{32} I d$. at 31 .

${ }^{33} I d$. at 32.

${ }^{34} I d$. at $41-42$.

${ }^{35} \mathrm{Id}$. at 57-120.

${ }^{36} I d$. at $125-26,140-41$.

${ }^{37} \mathrm{Id}$. at 126.

${ }^{38} \mathrm{Id}$. at 128. 
condensation and precipitation of atmospheric moisture would be, if not greater in total quantity, more frequent and less violent in discharge."39

Equally important to the enduring importance of Man and Nature to environmental and natural resources law is Marsh's early recognition that humans are not too insignificant to seriously affect physical and chemical geographical realities, not just biological. Indeed, human enterprises regularly upset ecosystems' deep relationships and alter those systems' balances, causing long-term "unforeseen and undesirable results.",40 (Indeed, the title Marsh first proposed for his book was "Man the Disturber of Nature's Harmonies." 41 For example, "[w]ith the extirpation of forests, all is changed"-_the climate becomes excessive, and the soil is alternately parched by the fervors of summer, and seared by the rigors of winter." 42 Precipitation events become more violent, soil is carried away, and rivers and lakes become choked on sediment. ${ }^{43}$ Similarly, humans have significantly changed the character of inhabited coasts both by reclaiming solid land from tidelands and wetlands, by "resist[ing new encroachments of the sea upon the land," 44 by draining and redirecting freshwaters, and by using groundwater. Marsh also noted some of the newer forms of significant changes humans might bring to natural geography. For example, cutting across more isthmuses - like the Isthmus of Panama - with canals like the Suez Canal could aid navigation in other parts of the world, but "[a] new channel may deflect strong currents from safe courses, and thus occasion destructive erosion of shores otherwise secure, or promote transportation of sand or slime to block up important harbors, or it may furnish a powerful enemy with dangerous facilities for hostile operations along the coast." 45 Hydraulic mining "is producing important geographical effects in California," where "the process is resorted to o a vastly greater scale than in any other modern engineering operations, and with results proportional to the means""[n]aked hills and fertile soils are alike washed away by the artificial torrent, and the material removed - vegetable mould, sand, gravel, pebbles - is carried down by the current and often spread over ground lying quite out of the reach of natural inundations, and burying it to the depth sometimes of twenty-five feet." "No "Nook before it had ever treated of subject of environmental abuse in such a comprehensive, systematic, and compelling fashion."47

\footnotetext{
${ }^{39} I d$. at 155 .

${ }^{40} \mathrm{Id}$. at 47.

${ }^{41}$ LOWENTHAL, supra note 6, at XX (Chapter 14, after fn 2).

${ }^{42}$ MARSH, supra note 26, at 224.

${ }^{43} I d$.

${ }^{44} I d$. at 297.

${ }^{45} \mathrm{Id}$. at $437-38$.

${ }^{46} \mathrm{Id}$. at 450.

${ }^{47}$ DORMAN, supra note 2, at 41 .
} 
Finally, Man and Nature also continues to be important because of Marsh's fullthroated commitment to conservation, including restoration. The New World, he emphasized, was in trouble:

Comparatively short as is the period through which the colonization of foreign lands by European emigrants extends, great and, it is to be feared, sometimes irreparable injury has already been done in the various processes by which man seeks to subjugate the virgin earth; and many provinces, first trodden by homo sapiens Europae within the last two centuries, begin to show signs of that melancholy dilapidation which is now driving the peasantry of Europe from their native hearths. $^{48}$

This decay, Marsh asserted, "should be arrested"49; humans had to act again, because their changes meant that nature could no longer heal itself. ${ }^{50}$ Specifically, "man's utmost ingenuity and energy must be tasked to renovate a nature drained, by his improvidence, of fountains which in a wise economy would have made plenteous and perennial sources of beauty, health, and wealth." 51 Moreover, law is an important component of the conservation approach, emerging directly from government's duty to supply public goods, which includes the environment as much as roads, canals, railroads, and a postal service. $^{52}$

As one might expect for a work from the 1870s, Marsh's science wasn't perfect. For example, he generally fails in Man and Nature to identify overuse of natural resources as an important human driver of ecological change, ${ }^{53}$ despite his work as Vermont's Fish Commissioner and his recognition there that greedy fishermen were part of the reason native fish stocks were declining. He considered forests to be the earth's most natural condition, positing that "the surface of the habitable earth, in all the climates and regions which have been the abodes of dense and civilized populations, was, with few exceptions, already covered with a forest growth when it first became the home of man." 54 His preference for forests also leads him to view even natural forces that change forests - for example, beavers and the creation of bogs - as "destructive in character.",55 Marsh's "Calvinist, Enlightenment, utilitarian progressivism predisposed him to segregate and

\footnotetext{
${ }^{48}$ MARSH, supra note 26, at 52.

${ }^{49} \mathrm{Id}$.

${ }^{50}$ LOWENTHAL, supra note 6, at XX (Chapter 14, after fn 15).

${ }^{51}$ MARSH, supra note 26, at 53.

${ }^{52} I d$. at 56.

${ }^{53}$ Even here, however, Marsh does note problems of over-consumption: "Man has too long forgotten that the earth was given to him for usufruct alone, not for consumption, still less for profligate waste." Id. at 41.

${ }^{54} \mathrm{Id}$. at 121.

${ }^{55}$ Id. at 37 .
} 
exalt humanity as above and at war with the cosmos, ${ }^{, 56}$ and he clearly identifies humanity as a species apart from nature, ${ }^{57}$ whose "self-conscious will" in acting upon nature pursues both primary and secondary, and short-term and long-term goals, operates as a different category of force than is exercised by animals like beavers. ${ }^{58} \mathrm{He}$ accepts without question the embedded stationarity and Balance of Nature model of a personified Nature left to her own devices, reflecting the dominant view of both contemporary catastrophists and uniformitarians:

Nature, left undisturbed, so fashions her territory as to give it almost unchanging permanence of form, outline, and proportion, except when shattered by geologic convulsions; and in these comparatively rare cases of derangement, she sets herself at once to repair the superficial damage, and to restore, as nearly as practicable, the former aspect of her dominion. In new countries, the natural inclination of the ground, the self-formed slopes and levels, are generally such as best secure the stability of the soil. They have been graded and lowered or elevated by frost and chemical forces and gravitation and the flow of water and vegetable deposit and the action of the winds, until, by a general compensation of conflicting forces, a condition of equilibrium has been readied which, without the action of man, would remain, with little fluctuation, for countless of ages. ${ }^{59}$

Finally, as his recurring references to the United States as a "new country" attest, Marsh wholly ignores (or, more charitably, may have been legitimately ignorant of) the pervasive influences of Native Americans on the geography and ecology of what became the United States and Canada. Indeed, Marsh downplays or ignores the influences of

${ }^{56}$ LowenthalL, supra note 6, at XX (Chapter 14 before fn 1).

57 "The fact that, of all organic beings, man alone is to be regarded as essentially a destructive power, and that he wields energies to resist which Nature - that nature whom all material like ad all inorganic substance obey - is wholly impotent, tends to prove that, though living in physical nature, he is not part of her, that he is of more exalted parentage, and belongs to a higher order of existences, than those which are born of her womb and live in blind submission to her dictates." MARSH, supra note 26, at 42.

${ }^{58} I d$. at 47.

${ }^{59} I d$. at 36. "In fine, in countries untrodden by man, the proportions and relative positions of land and water, the atmospheric precipitation and evaporation, the thermometric mean, and the distribution of vegetable and animal life, are maintained by natural compensations, in a state of approximate equilibrium, and are subject to appreciable change only from geological influences so slow in their operation that the geographical conditions may be regarded as substantially constant and immutable." Id. at 40. See also $i d$. at 44 ("without man, lower animal and spontaneous vegetable life would have been practically constant in type, distribution, and proportion, and the physical geography of the earth would have remained undisturbed for indefinite periods"). 
"uncivilized" cultures more generally. For example, on the subject of peat bogs, Marsh notes that "[i]n countries somewhat further advanced in civilization that those occupied by the North American Indians, as in mediaeval Ireland, the formation of bogs may be commenced by the neglect of man to remove, from the natural channels of superficial drainage, the tops and branches of trees felled for the various purposes to which wood is applicable in his rude industry ...." ${ }^{\circ 60}$ More generally, "[p]urely untutored humanity ... interferes comparatively little with the arrangements of nature," and while the "earliest dawn of civilization" was accompanied by "domestication of the organic world," "the conquest of inorganic nature [belongs] almost [] exclusively to the most advanced stages of artificial culture. ${ }^{, 61}$

Moreover, as the numerous and fascinating footnotes in Man and Nature reveal, Marsh, like Newton, "stood on the shoulders of giants." In particular, his immediate predecessors Alexander von Humboldt and Charles Darwin both influenced him tremendously, the former through his systemic view of nature and the latter through his various exegeses of change in living organisms. When Humboldt died in 1859, he was considered the greatest scientist of his day. Like Marsh, Humboldt's interests were broad, his publications many (Marsh devoted an entire section of his library to Humboldt's works), and his views of the universe shaped by many travels. However, Humboldt's Cosmos, the best-selling first volume of which appeared in 1845, perhaps most succinctly illustrates the connections between the two thinkers. Humboldt sought to know everything, and Cosmos journeys from outer space to the inner earth, reflecting Humboldt's views that "[e]verything was part of this "never-ending activity of the animated forces," "and that nature was "a 'living whole' where organisms were bond together in a 'net-like intricate fabric'." ${ }^{62}$ Like Marsh, Humboldt brought together a wide range of subjects, but his interest was in showing connections. For example, "Humboldt was the first to understand climate as a system of complex correlations between the atmosphere, oceans, and landmasses." ${ }^{\circ 3}$ Humboldt also occasioned some of Marsh's "aha!" moments. For example, as he traveled in Turkey, Egypt, Greece, and the Levant, "[e]verything that Marsh has read in Humboldt's books suddenly made sense," including Humboldt's observation that humanity "left trails of destruction . . . 'wherever he stepped'." ${ }^{64}$ Darwin, in turn, published On the Origin of Species in 1859, and Marsh was quite familiar with Darwin's work more broadly, as the various references to Darwin in Man and Nature attest. Notably, Marsh took pains to distinguish Man and Nature from

${ }^{60}$ Id. at 39.

${ }^{61}$ Id. at 45. Notably, however, Marsh's conception of "civilized" culture was broader that many of his contemporaries and included more than white, European- or Greco-Romanderived "western civilization." His experiences in Turkey and the Holy Land had given him great respect for Islamic civilization, for example. LOWENTHAL, supra note 6, at XX. 62 Andrea Wulf, The Invention of Nature: AleXander von Humboldt's New WORLD 290 (Viking Books first ed. paperback 2016).

${ }^{63} \mathrm{Id}$. at 291.

${ }^{64}$ Id. at $339-40$. 
Darwin's work, noting that while "[ $\mathrm{t}]$ he modification of organic species by domestication is a branch of philosophic inquiry which we may almost say has been created by Darwin," "the geographical results of these modifications do not appear to have yet been made a subject of scientific investigation." ${ }^{65}$ In addition, both On the Origin of Species and Man and Nature focus on change in nature, often slow and gradual, and both books upended traditional views about humanity's place in the universe.

Nevertheless, Man and Nature was a pioneering work in its own right. "Next to Darwin's On the Origin of Species, Marsh's Man and Nature of 1864 was the most influential text of its time to link culture with nature, science with society, landscape with history." "66 Cultural historians also rank Man and Nature with Aldo Leopold's A Sand County Almanac (1949) and Rachel Carson's Silent Spring (1962) in terms of its role in reconceptualizing humans' relationship to their surroundings in a politically salient way. $^{67}$

No one had ever pointed out the total effect of all the works of man. No one had ever before turned to the study of the earth as the home of mankind. Others had voiced concern about the silted rivers, deforested hills, but only Marsh saw the total interdependency of the environmental and social relationships. The 18th Century naturalists had considered man's action as beneficial, order and cultivation being wrested from chaos. Marsh knew better. ${ }^{68}$

Man and Nature "made a growing public aware of how massively humans transform their milieus," directly contradicting the popular perception at the time that human impacts "were largely benign, [and] that malign effects were trivial or ephemeral." 69 Indeed, "[m]ost inquirers before Marsh had trusted earth's plentitude, assumed resources inexhaustible, and never doubted that they could and should master nature; the conquest was God's command and national destiny.",70 Environmentalist and writer Wallace Stegner called Man and Nature "the 'rudest kick in the face' to America's optimism," exhorting Americans to be more cautious in their race to develop their country. ${ }^{71}$

Marsh's work both influenced and anticipated natural resources and environmental law and policy in the United States: "Man and Nature was the first work

${ }^{65}$ MARSH, supra note 26, at 25.

${ }^{66}$ LOWENTHAL, supra note 6, at XX (Preface).

${ }^{67}$ William Cronon, Forward: Look Back to Look Forward, in LowENTHAL, supra note 6, at XX.

${ }^{68}$ CURTIS, CURTIS, \& Lieberman, supra note 5, at 104.

${ }^{69}$ LOWENTHAL, supra note 6, at XX (Chapter 13, near fn 3).

${ }^{70} \mathrm{Id}$. at XX (Chapter 13, after fn 20).

${ }^{71}$ WuLF, supra note 62, at 350. 
of natural history fundamentally to influence American politics."72 For example, Man and Nature helped to crystallize land conservation efforts in the United States, underscored by the creation of Yellowstone as the first National Park in 1872. Marsh himself took significant interest in preserving landscapes through protective legal designation, becoming for example "an early and active advocate of setting aside part of the Adirondack wilderness as parkland."73 John Muir would read and be influenced by Man and Nature. Man and Nature remained the "only general work in the field" for decades, and "[t]he third (1884) edition was last reprinted in 1907, on the eve of the White House Conference that led Theodore Roosevelt to create a national conservation commission under Gifford Pinchot,"74 the predecessor agency to the U.S. Forest Service. Marsh's insights regained popularity again during the 1930s Dust Bowl, and "Marsh's prescient ecological warning were hailed as a 1955 Princeton symposium, 'Man's Role in Changing the Face of the Earth." ",75 Man and Nature was finally reissued in print in 1965, just as the United States' nascent environmental movement was gaining steam, and President Lyndon B. Johnson's Secretary of the Interior Stewart Udall credited the book with helping to create the United States' conservation movement, ${ }^{76}$ calling it "'the beginning of land wisdom in this country.",77

As might be expected from Marsh's emphasis on forests, Man and Nature was particularly instrumental in launching forest conservation efforts. For example, "Marsh's warnings led Franklin B. Hough at the American Association for the Advancement of Science in 1873 to petition Congress for a national forestry commission," relying heavily on Man and Nature, and "[e]very leading forestry figure was inspired by the book and sought Marsh's advice."78 Man and Nature both "encouraged the passage of the 1873 Timber Culture Act to encourage settlers on the Great Plains to plant trees as a way of increasing rainfall" and laid the groundwork for protecting U.S. forests at both the state and federal levels. "Several state forestry commissions founded in the 1870 s were also attributable in part to Marsh's consciousness-raising efforts," leading within a decade of his death to state forest reserves. ${ }^{80}$ At the federal level, Hough's petition to Congress bore fruit, and in 1876 Congress created the Office of the Special Agent for forest research within the Department of Agriculture. Hough served as the head of this office, which Congress expanded in 1881 to the Division of Forestry. The Forest Reserve Act of 1891 authorized the withdrawal of federal lands for forest reserves, which fell under the U.S.

\footnotetext{
${ }^{72} I d$.

${ }^{73}$ LOWENTHAL, supra note 6, at XX (Chapter 18, after fn 41).

${ }^{74} \mathrm{Id}$. at XX (Chapter 14, by fn 34).

${ }^{75} \mathrm{Id}$. at XX (Chapter 18, before fn 12).

${ }^{76}$ CURTIS, CURTIS, \& LiEBERMAN, supra note 5, at 122.

${ }^{77}$ LOWENTHAL, supra note 6, at XX (quoting Stewart Udall) (Chapter 14, by fn 43).

${ }^{78}$ Id. at XX (Chapter 14, fn 28).

${ }^{79}$ Cronon, supra note 67 , at XX.

${ }^{80}$ DoRmAN, supra note 2, at 42-43.
} 
Department of the Interior's jurisdiction. The first such withdrawal occurred on March 30, 1891, establishing the Yellowstone Park Timber and Land Reserve, which eventually evolved into the Targhee, Teton, Wyoming, Bonneville, Absaroka, Shoshone, and Beartooth National Forests that surround Yellowstone and Grand Teton National Parks.

In 1901, the Division of Forestry became the Bureau of Forestry, and in 1905, Congress used the Transfer Act of 1905 to move the federal forest reserves from Interior's jurisdiction to the Bureau's, which became known as the United States Forest Service. Gifford Pinchot, the first Chief Forester of the U.S. Forest Service, knew Man and Nature well, and "[t]he U.S. Forest Service, the Sierra Club, and finally even the timber companies acted within an ecological mindset whose broad premises Marsh had set." 81 By 1907, President Roosevelt had doubled the acreage of the National Forest reserves. In 1911, Congress passed the Weeks Act, allowing the federal government to purchase private land to protect stream flow and to manage the purchased lands as national forests. In effect, the Weeks Act allowed the growing national forest system to extend into the eastern states - including back to Marsh's state of birth, through the establishment of what is now the Green Mountain National Forest. Today there are 154 National Forests throughout the United States, covering more than 192 million acres.

Man and Nature also greatly influenced forestry practices in Europe, including France and Italy, and in India, Australia, New Zealand, South Africa, and Japan. Notably, when Marsh died in Europe in 1882 at the age of 81, "his coffin was borne down the mountain by an honor guard of foresters," $" 82$ a tribute to how quickly he had influenced forestry policy and management.

Importantly, Marsh's conservation ethic included careful human use of the earth, and that balanced approach also can be traced forward into 21st-century U.S. environmental and natural resources law. Unlike both the caricature of his near contemporary Henry David Thoreau and the actual aims of 1960s ecological reformers who sought to limit all human impact on the environment (for example, by preserving wilderness), Marsh did not oppose all human action that changed the environment. He admitted, for example, that "[ $\mathrm{t}]$ he physical revolutions thus wrought by man have not indeed all been destructive to human interests, and the heaviest blows he has inflicted upon nature have not been wholly without their compensations." ${ }^{~} 3$ Instead, and again anticipating contemporary issues in environmental and natural resources law, he examined such changes through a cost-benefit approach, concluding in many circumstances that the benefits to humans outweighed the adverse ecological effects. His point in Man and Nature was more subtle: that humans should not act in ignorance,

${ }^{81}$ LOWENTHAL, supra note 6, at XX (Chapter 14, after fn 29).

${ }^{82}$ DORMAN, supra note 2, at 43.

${ }^{83}$ MARSH, supra note 26, at 25. 
unaware of their potential to wreak long-term and damaging change that they themselves would come to regret. ${ }^{84}$

In this sense, therefore, there is a direct line of self-awareness connecting Man and Nature to the United States' 1969 National Environmental Policy Act (NEPA) and to environmental impact analysis requirements more generally. Indeed, Marsh both emphasized the importance of cumulative impacts over time and was unwilling to accept uncertainty as an excuse for acting greedily and rashly. Marsh distinguished law and nature in this regard:

It is a legal maxim that "the law concerneth not itself with trifles," de minimis non curat lex; but in the vocabulary of nature, little and great are terms of comparison only; she knows no trifles, and her laws are as inflexible in dealing with an atom as with a continent or planet.

The human operations mentioned ...., therefore, do act in the ways ascribed to them, though our limited faculties are at present, perhaps forever, incapable of weighing their immediate, still more their ultimate consequences. But our inability to assign definite values to these causes of the disturbance of natural arrangements is not a reason for ignoring the existence of such causes in any general view of the relations between man and nature, and we are never justified in assuming a force to be insignificant because its measure is unknown, or even because no physical effect can now be traced to its origin. ${ }^{85}$

In addition, Marsh recognized profoundly that human well-being is intimately intertwined with natural functions, anticipating the contemporary focus on this interrelationship that is generally captured, albeit imperfectly, in the concept of social-ecological systems.

Finally, Marsh also recognized that geographical and ecological systems do not always respond as humans intend, emphasizing the importance of "the contingent and unsought results which have flowed" from human interactions with the environment. ${ }^{86}$ He of course lacked the 20th- and 21 st-century terminology to describe complexity theory, systems theory, complex adaptive systems, and panarchy, but his recognition of unintended consequences and realization that nature does not always behave as humans expect encapsulate the core insight for natural resources managers of these later developments in ecological and social-ecological theory. This core insight has, if anything, become even more critical in the Anthropocene, in which we are living out the

${ }^{84} \mathrm{Id}$. at 44 (for humanity to thrive, "a certain measure of transformation of terrestrial surface, of suppression of natural, and stimulation of artificially modified productivity becomes necessary," but "[t]his measure man has unfortunately exceeded.").

${ }^{85}$ Id. at $457-58$.

${ }^{86} \mathrm{Id}$. at 36. 
truly global and long-term consequences of industrialization and the increasing dependence, already accelerating in Marsh's time, on fossil fuels-namely, global climate change and ocean acidification. Management surprise and a continually changing set of natural and coupled social-ecological systems have become our new reality, and yet, as in Marsh's time, there remain those who will not see or who still hew to the worldview of balance and divine providence that dominated Marsh's America. As Marsh biographer David Lowenthal has summarized, "Unlike most modern environmentalists, Marsh had come to terms with nature's 'baffling complexity, its inherent unpredictability, its daily turbulence," $", 87$ anticipating by a century and a half a mindset that now has become universally necessary for effective environmental management.

It is perhaps the American West, however, that provides one of the most enduring monuments both to Marsh's general influence and to the continuing relevance of his observations in Man and Nature about the unintended consequences of humanity's often overexuberant and unreflective manipulation of the physical world. A bit ironically, Marsh became one of the architects of what is arguably the greatest geographical transformation in the United States: the human-engineered irrigation of the West. Toward the end of his life, at the request of the U.S. Commissioner of Agriculture, Marsh wrote an influential report on irrigation, recommending a thorough survey of the American West to see whether and how to invest in irrigation projects there. His report eventually helped prompt Congress to create the Bureau of Land Reclamation and to enact the Reclamation Act of 1902.

That agency and that law have made absolutely clear humanity's capacity to transform an entire region. Pursuant to the Reclamation Act, the Bureau of Reclamation operates in 17 western states, from the west coast to the line of states from North Dakota south to Texas. Since 1905, when it built its first project, the Klamath Basin project straddling southern Oregon and northern California, the Bureau has built more than 600 dams and reservoirs in the West, including Hoover Dam on the Colorado River and Grand Coulee Dam on the Columbia River. Its 338 reservoirs have a total storage capacity of 140 million acre-feet (an acre-foot contains 325,851 gallons of water), and the Bureau remains the United States' largest water wholesaler, delivering 10 trillion gallons of water each year to 31 million customers. One out of five farmers in the West still rely of Bureau projects for irrigation, watering 10 million acres of cropland. The Bureau also operates 53 hydroelectric facilities that produce, on average, 40 billion kilowatt-hours of electricity each year.

While the many large-scale dam-and-reservoir Reclamation projects allowed farming, ranching, and settlement of the arid West, they came at an environmental cost. No rivers of any size in the West flow free, dozens of fish and other river-dependent species have declined so much that they are listed for protection under the federal

${ }^{87}$ LOWENTHAL, supra note 6, at XX (quoting MARSH, supra note 26, at 91-92) (Chapter 18 , after fn 58). 
Endangered Species Act, few coastal estuaries receive the freshwater they need for productive ecosystems, and the huge reservoirs have drowned habitats and affected climate. Contradicting Marsh's cautions to tread slowly and carefully, engineers built effectively every dam that could be built, regardless of how marginal the human benefit and how high the ecological cost.

The result is what Marc Reisner famously dubbed "the Cadillac Desert." Reisner, like Marsh, recognized that the engineered changes to the physical world that make human settlement and comfort possible also have a habit of coming back to bite us, complete with unintended consequences:

Like so many great and extravagant achievements, from the fountains of Rome to the federal deficit, the immense national damconstruction program that allowed civilization to flourish in the deserts of the West contains seeds of disintegration; it is the old saw about an empire's rising higher and higher and having farther and farther to fall. ${ }^{89}$

None of this is to say that we shouldn't have gone out and tried to civilize the arid West by building water projects and dams. It is merely to suggest that we overreached ourselves. What we achieved may be spectacular; in another sense, though, we achieved the obverse of our goals. The Bureau of Reclamation set out to help the small farmers of the West but ended up making a lot of rich farmers even wealthier at the small farmers' expense. ... We set out to tame the rivers and ended up killing them. We set out to make the American West secure; what we really did was make ourselves rich and our descendants insecure. Few of them are apt to regret that we built Hoover Dam; on balance, however, they may find themselves wishing that we had left things pretty much as they were. ${ }^{90}$

George Perkins Marsh first published Man and Nature 155 years ago, but his basic lessons remain relevant to U.S. environmental and natural resources law and policy far beyond forest protection and reforestation. Indeed. given the widespread agreement that we have entered the Anthropocene, his lessons are perhaps even more relevant now than they were at the beginning of the conservation era.

88 Marc Reisner, Cadillac Desert: The American West and Its Disappearing WATER (1993 Viking Penguin paperback ed.).

${ }^{89} \mathrm{Id}$. at 480 .

${ }^{90} \mathrm{Id}$. at 486. 
Humanity has set climate change in motion, the impacts of which-from the behavior of glaciers in Greenland and Antarctica to the worsening of tropical storms to the burning of Norwegian sub-Arctic forests and the Amazon rainforest-continually surprise us. Humanity has set ocean acidification in motion, perhaps signing the death warrant for coral reefs worldwide. We have covered the planet in plastic and seasoned it with an increasing variety of toxics and are still figuring out the extent of that damage. Cumulatively, we appear to have set in motion the planet's sixth mass extinction event, to who knows what end.

Marsh, in other words, hadn't seen anything yet - and he nevertheless still got the core message right. Humans are agents of massive geographical and ecological change. However, we never have a complete idea of what we're doing because we are acting on complex adaptive systems in which causation is inherently problematic and results inherently uncertain. Changes accumulate and feed each other over time, and those synergies often lead to results that we neither wanted nor like. The damage, once done, is often hard to undo, warranting caution.

Unfortunately, humanity has not yet fully absorbed Marsh's warning. The American West - and the rest of the world, for that matter-continues to cope with the consequences of human modifications to planetary systems, from Marsh's deforestation and dammed rivers to urbanized landscapes to climate change. If Marsh could observe these "new" challenges shaping contemporary environmental and natural resources law and policy, he might just shake his head in frustration and mutter, "I told you so!"

However, Marsh also saw ways out of the transformation trap-exit routes from prior behavior that we must hope can still work to thwart at least the worst of the futures that we have probably already set in motion. Human agency can work to better the environment as well as to destroy it. We can conserve what remains and try to restore some of the systems that have changed-or at least, using modern parlance and acknowledging climate change realities, we can act to preserve and restore ecosystem function and the production of ecosystem services, building system resilience, even if the system in question is partially or wholly transformed from what it used to be. Above all, we can be less greedy, curbing our desires to consume and control the natural systems within which we are embedded in favor of a far more modest footprint on the planet. 